\title{
PENGARUH PEMBERIAN SENAM YOGA TERHADAP KESEIMBANGAN STATIS PADA LANSIA 2019
}

\author{
Siti Munawarah ${ }^{1}$, Yunda Triariani ${ }^{2}$ \\ Program Ilmu Fisioterapi STIKes Fort De Kock \\ Email: sitimunawarah@fdk.ac.id
}

Submitted: 18-07-2019, Reviewer: 22-07-2019, Accepted: 28-07-2019

\begin{abstract}
ABSTRACK
Balance is the ability to maintain the projection of the center of the body on the supporting foundation both when standing, sitting, transit and walking. According to the results of the initial survey the number of elderly $31 \%$ to $48 \%$ of the elderly fell due to a balance disorder. The purpose of this study was to determine the effect of yoga gymnastics on the static balance of the elderly at the Tigo Baleh Bukittinggi health center. The design of this study is Quasi experiment desaign one PreTest-PostTest group. Using the Wilcoxon Signed Rank Test, the sampling technique was purposive sampling with a sample of 30 respondents with tinetti measuring instruments. The results of this study were obtained on average before being given Gymnastics Yoga 18.50 and after being given Yoga Gymnastics 25.33 and $P$-value $0.0005<(0.05=$ Alpha $)$. thus drawing conclusions about the effect of yoga exercises on static balance in the elderly. It can be concluded that giving Yoga Gymnastics can improve static balance in the elderly. And it is recommended for the elderly to apply yoga exercises to maintain balance.
\end{abstract}

Keywords : Gymnastics on Static Balance in Elderly.

\begin{abstract}
ABSTRAK
Keseimbangan adalah kemampuan untuk mempertahankan proyeksi pusat tubuh pada landasan penunjang baik saat berdiri, duduk, transit dan berjalan. Menurut hasil survey awal jumlah lansia $31 \%$ sampai 48\% lansia jatuh karena gangguan keseimbangan. Tujuan penelitian ini adalah untuk mengetahui Pengaruh pemberian senam yoga terhadap keseimbangan statis lansia di puskesmas Tigo Baleh Bukittinggi. Desain penelitian ini adalah Quasi eksperiment desaign one grup PreTest-PostTest. Menggunakan Wilcoxon Signed Rank Test, teknik pengambilan sampel purposive sampling dengan sampel 30 responden dengan alat ukur tinetti sebelum dan sesudah 6 kali perlakuan pada tanggal 25 Mei sampai 22 Juni 2019. Hasil penelitian ini didapatkan rata-rata sebelum di berikan Senam Yoga 18.50 dan sesudah di berikan Senam Yoga 25.33 dan P-value $0,0005<(0,05=$ Alpha $)$. dengan itu ditarik kesimpulan ada pengaruh pemberian senam yoga terhadap keseimbangan statis pada lansia. Dapat disimpulkan bahwa pemberian Senam Yoga dapat meningkatkan keseimbangan statis pada lansia. Dan disarankan kepada lansia untuk menerapkan latihan senam yoga untuk mempertahankan keseimbangan.
\end{abstract}

\section{Kata Kunci : Senam Yoga Terhadap Keseimbangan Statis Pada Lansia.}

\section{PENDAHULUAN}

Menua adalah keadaan yang terjadi didalam kehidupan manusia. Proses menua bukanlah suatu penyakit. Menua merupakan proses menghilangnya secara perlahan kemampuan jaringan tubuh untuk mempertahankan struktur dan fungsi normal,(Boedhi, 2014). Salah satu perubahan anatomi pada sistem muskloskeletal yang terjadi pada proses menua adalah berkurangnya massa otot, degenerasi miofibril, tendon mengerut dan atrofi serabut otot (Panti, Omega and Indriati, 2012). Perubahan anatomi tersebut berdampak pada penurunan kekuatan otot. Kekuatan otot merupakan komponen, utama dari keseimbangan tubuh (Guccione, 2000 dalam Kusnanto, 
2007). Proses ini ditandai dengan terjadinya kehilangan jaringan pada susunan saraf, otot, dan jaringan lain secara perlahan sehingga tubuh mati sedikit demi sedikit (Maryam et al., 2008) Lansia adalah seseorang yang berusia 60 tahun ke atas baik pria maupun wanita, yang masih aktif beraktifitas dan bekerja ataupun mereka yang tidak sehingga bergantung kepada orang lain untuk menghidupi dirinya (Potter \& Perry, 2006). Faktor-faktor yang mempengaruhi tingkat kemandirian lansia dalam melakukan aktivitas sehari-hari seperti umur dan status perkembangan kesehatan fisiologis, fungsi kognitif, fungsi psikososial, tingkat stres, ritme blog, status mental, pelayanan kesehatan. Adapun peran fisioterapi yang dapat dilakukan untuk menentukan kemampuan fungsional pada lansia salah satunya adalah dengan melakukan senam yoga (Hardywinoto, 2007).

Birren and Enner, membedakan usia menjadi tiga: usia biologis: yang menunjukkan kepada jangka waktu seseorang sejak lahirnya berada dalam keadaan hidup dan mati, usia pskologis menunjuk pada kemampuan seseorang untuk mengadakan penyesuaianpenyesuaian kepada situasi yang dihadapinya. Usia sosial: yang menunjuk kepada peran-peran yang diharapkan atau diberikan masyarakat kepada seseorang sehubungan dengan usianya. Perubahanperubahan tersebut dapat mengakibatkan gangguan pada sistem tubuh dan penyakit degeneratif dan merupakan dampak fungsional negatif seperti penurunan produktifitas kemandirian dan kualitas hidup.(Birren, 1995)

Berdasarkan survey di masyarakat Amerika Serikat, sekitar 30\% lansia umur lebih dari 65 tahun jatuh setiap tahunnya, separuh dari angka tersebut mengalami patah tulang. Jatuh adalah penyebab utama kematian terkait cidera dan perawatan rumah sakit pada orang umur 75 tahun dan lebih tua. Pada penelitian di Inggris terhadap gangguan-gangguan fisik salah satunya yaitu keseimbangan berdiri sebesar $50 \%$ dari berbagai gangguan yang terjadi pada lansia dapat menyebabkan terganggunya atau menurunnya kualitas hidup pada lansia sehingga usia harapan hidup (Life Expenctancy) juga akan menurun. Secara umum lansia memiliki penurunan pada kekuatan, fleksibilitas sendi, dan keseimbangan.

Indonesia merupakan negara dengan era penduduk berstruktur lansia karena jumlah yang berusia 60 tahun keatas semakin meningkat dan lebih dari $7 \%$ (Kemenkes RI Nomor 264, 2010,)(Kemenkes RI, 2017) peningkatan jumlah lansia berdampak pada status kesehatan terkait dengan faktor resiko biologis dan usia pada lansia direfleksikan dengan perubahan-perubahan terkait dengan usia. saat ini di Indonesia terdapat sekitar 10 juta orang yang berusia di atas 65 tahun $(46 \%$ dari seluruh jumlah penduduk) Bahkan, indonesia termasuk salah satu negara, yang jumlah penduduknya lansianya bertambah paling cepat di Asia Tenggara versayanti (Nur, 2009). Angka harapan hidup penduduk indonesia berdasarkan data biro pusat statistik pada tahun 1968 (BPS, 2000: 1) adalah " 45,7 tahun, pada tahun 1980; 55,3 tahun, pada tahun 1985 : 58,19 tahun, pada tahun 1990: 61,12 tahun, dan tahun 1995: 60,05 tahun serta tahun 2000: 64,05 tahun".( Birren, J, 1995)(Birren, 1995)

Yoga dapat dilakukan oleh semua kalangan dari anak-anak hingga lanjut usia. Yoga sangat mudah dilakukan dan bukan latihan yang terkait dengan agama tertentu. Patanjali (Panti, 2012)(Panti, Omega and Indriati, 2012) menyebutkan bahwa yoga bukan merupakan agama dan setiap orang sesungguhnya melakukan yoga. Setiap orang melakukan yoga, dengan tujuan untuk mendapatkan kebahagiaan yang sebenarnya dapat diperoleh melalui kesadaran terhadap diri. Selama ini manusia belum sepenuhnya menyadari bahwa kebaagiaan diperoleh dari menyadari diri sendiri. Manusia merasa bahwa kebahagiaan didapat 
melalui objek dari luar yang sering di anggap dapat memberikan kepuasan (Perdana, 2016)(Perdana, 2016).

Yoga yaitu aktifitas gerakan oleh tubuh dan juga pikiran yang sangat fokus pada kekuatan dan pernapasan untuk meningkatkan kualitas mental dan fisik postur, rangkaian gerakan pernapasan adalah komponen utama yoga.

Manfaat Yoga yaitu melatih keseimbangan, melancarkan fungsi organ, meningkatkan konsentrasi dan kecerdasan, menyiagakan tubuh dan mengurangi depresi stress.

Keseimbangan yaitu kemampuan untuk mempertahankan proyeksi pusat tubuh pada landasan penunjang baik saat berdiri, duduk, transit, dan berjalan (Winner, 1995 dalam Howe, et al, 2008).(Howe, 2008) Keseimbangan juga merupakan bereaksi secara cepat dan efisien untuk menjaga stabilitas postual seperti, sebelum, selama, dan setelah pergerakan serta dalam berespon terhadap gangguan eksternal. Keseimbangan dipertahankan oleh integrasi yang dinamik dan eksternal yang melibatkan lingkungan (Gribble \& Hertel, 2003).(Gribble and Hertel, 2003)

Keseimbangan ada dua tipe yaitu keseimbangan statis dan keseimbangan dinamis. Keseimbangan statis mempertahankan posisi yang tidak bergerak atau berubah sedangkan keseimbangan dinamis melibatkan kontrol tubuh karena tubuh bergerak dalam ruang (National Throws Coaches Association).(Turocy et al., 2011).

Penelitian ini bertujuan untuk mengetahui pengaruh pemberian senam yoga terhadap keseimbangan statis pada lansia.

\section{METODE PENELITIAN}

Penelitian merupakan pendekatan Quasi Exsperiment dengan metode pendekatan Pretest-Posttest dan pengambilan sampel yaitu dengan cara Purposive Sampling(Notoadmojo, 2018)Penelitian dilakukan pada bulan 22 Mei- 22 Juni 2019. Sampel yang digunakan pada penelitian terdiri dari 30 orang lansia kisaran umur 45-60 tahun yang berada di Puskesmas Tigobaleh Bukittinggi. Analisis data pada penelitian dilakukan dengan uji Wilcoxon membandingkan antara sebelum dan sesudah pemberian intervensi berupa senam yoga.

\section{POPULASI DAN SAMPEL}

Pada penelitian ini pengambilan sampel dilakukan dengan Purposive Sampling yaitu yang memenuhi kriteria inklusi yang telah ditetapkan dalam penelitian ini terdiri dari lansia umur 45-60 tahun, lansia yang dapat berkomunikasi dengan baik, lansia yang memiliki gangguan keseimbangan. Adapun kriteria ekslusi dari penelitian ini yaitu lansia yang menderita penyakit jantung, parkinson, hipertensi, gangguan muskuloskeletal, kontakur, spasme, fraktur.

\section{HASIL DAN PEMBAHASAN}

\section{A. Analisa Univariat}

Analisa univariat digunakan untuk mendeskripsikan masing-masing variabel yang diteliti, yaitu untuk

Tabel 1. Rata - Rata Kesejmbangan Statis Responden Sebelum Pelaksanaan Senam Yoga di Puskesmas Tigo Baleh Bukittinggi Tahun 2019

\begin{tabular}{cccccc}
\hline Variabel & $\mathbf{N}$ & Mean & Min & Max & SD \\
\hline $\begin{array}{c}\text { Sebelum } \\
\text { Latihan }\end{array}$ & 30 & 18.50 & 16 & 21 & 1.503 \\
\hline Variabel & $\mathrm{N}$ & Mean & Min & Max & SD \\
\hline $\begin{array}{c}\text { Sesudah } \\
\text { Latihan }\end{array}$ & 30 & 25.33 & 21 & 28 & 1.647 \\
\hline
\end{tabular}


mengetahui rata- rata keseimbangan statis pada lansia sebelum dan sesudah diberikan intervensi senam yoga di Puskesmas Tigo Baleh Bukittinggi.

Lansia didefenisikan sebagai orang yang kemampuan fungsionalnya dipengaruhi oleh perubahan akibat penuaan dan faktor resiko Lansia tidak hanya berdasarkan umur kronologis tetapi berdasarkan pada karakteristik fisiologis dan psikososial dengan maturitas Depkes RI, 2009. Masalah keseimbangan pada lansia yang paling sering disebabkan oleh kondisi multi faktor yang dapat mencakup penurunan terkait usia atau penyakit dalam sistem keseimbangan. Penyebab berkurangnya keseimbangan pada lansia dapat berupa kelemahan otot, hilangnya propioception, dan ketidak mampuan untuk mengendalikan goyangan postural yang normal. ada banyak faktor resiko untuk jatuh yaitu: kelemahan otot, riwayat jatuh, gangguan visual, gangguan kognitif, osteoartritis. Perubahan terkait usia dalam sensimotor dan sistem neuromuscular secara negatif mempengaruhi kinerja kontrol postural statis dan dinamis bahkan pada orang dewasa yang sehat yang mengarah pada peningkatan resiko jatuh. Penuaan normal ditandai dengan penurunan masa otot dan penurunan masa tulang dan otot dan peningkatan adipositas. Penurunan masa otot dan penurunan kekuatan otot menyebabkan resiko patah tulang, kelemahan, penurunan kualitas hidup dan kehilangan indepedensi. Perubahan dalam muskuloskeletal ini mencerminkan proses penuaan serta konsekuensi dari berkurangnya katiifitas fisik. Otot yang terbuang pada orang tua disebut "sacropaenia" ganmgguan ini mengakibatkan insiden jatuh dan patah tulang yang lebih tinggi dan penurunan fungsional.kekuatan otot rangka juga berkurang seiring dengan bertambahnya usia. Penurunan kekuatan otot ini menyebabkan masalah dalam mobilitas fisik dan aktivitas sehari-hari. Jumlah total serat otot berkurang karena kapasitas produktif sel yang tertekan untuk menghasilkan protein. Ada penurunan ukuran sel otot, dan jaringan bersama dengan total kehilangan kekuatan otot, masa otot, dan kekuatan otot semua kelompok otot utama seperti, deltoid, bicep, trisep, dan gastronemius. Dengan penuaan racun kimia menumpuk didalam tubuh dan jaringan, secara keseluruhan ini merusak integritas sel otot. Aktifitas fisik juga berkurang dengan bertambahnya usia, karena perubahan gaya hidup (Krishna, 2019).

Hasil penelitian ini sejalan dengan penelitian yang telah dilakukan oleh Dheli, 2016. Tentang pengaruh senam yoga pada keseimbangan dalam populasi usia lanjut. Berdasarkan analisis data dapat diketahui adanya perbedaan hasil antara sebelum dengan mean 44,08 dan sesudah dengan mean 48,62 dalam pemberian perlakuan senam yoga.

Menurut asumsi peneliti sebelum pelaksanaan senam yoga keseimbangan statis responden berada pada rentang tidak baik, dimana ratarata keseimbangan pada lansia yaitu 18.50 Sehingga sebelum dilakukan intevensi tidak ditemukannya responden dengan kategori keseimbangan statis normal. Berkurangnya kemampuan responden dalam mempertahankan keseimbangan dalam saat diam dipengaruhi oleh menurunnya kemampuan degenerasi berhubungan dengan faktor usia, perubahan fungsional otot yaitu penurunan kekuatan dan kontraksi otot, elastisitas dan flesibilitas otot yang mempengaruhi terhadap kecepatan dan waktu reaksi pada lansia khususnya otot-otot panggul, 
kaki, dan lutut yang berperan penting dalam mempertahankan keseimbangan postural saat dalam mempertahankan posisi. Sebelum pelaksanaan senam yoga, diketahui bahwa lansia terlihat kesulitan dalam mempertahankan posisi, pada saat responden duduk dan diberi sedikit goyangan atau dorongan responden tampak kesulitan melawan dorongan, dan responden tampak reflek bergantung atau tampak menahaan posisi badan dengan tangan bergantung ditepi kursi. Berdasarkan hasil yang telah didapat maka disimpulkan bahwa umur lansia yang rentan terkena gangguan keseimbangan yaitu dari umur 55-64, dengan jenis kelamin perempuan dan pekerjaan ibu rumah tangga.

Berdasarkan penelitian yang dilakukan pada 30 responden di puskesmas Tigo Baleh Bukittinggi Tahun 2019 yang mengalami gangguan keseimbangan statis pada lansia setelah diberikan perlakuan 6 kali pelaksanaan senam yoga diketahui bahwa terjadi peningkatan keseimbangan statis pada lansia, dimana setelah melakukan senam yoga responden sudah bisa mempertahankan posisi dengan cukup baik tanpa bergantung untuk mempertahankan posisi, dimana ratarata keseimbangan didapat yaitu 25.33 Dengan nilai minimal yaitu 21 dan nilai maksimal 28.

Senam Yoga adalah aktifitas gerakan oleh tubuh dan juga gerakan oleh tubuh dan juga pikiran yang sangat fokus pada kekuatan dan pernapasan untuk meningkatkan kualitas mental dan fisik postur, rangkaian gerakan pernapasan adalah komponen utama yoga. Yoga yaitu pendekatan tubuh pikiran yang dipraktekan secara umum yang memiliki komponen utama seperti meditasi, pernapasan, dan aktivitas atau postur. Peningkatan kekuatan otot, kelenturan, rentang gerak, energi, relaksasi, penurunan nyeri, peningkatan kualitas tidur, pengurangan stress dan kontrol terhadap parameter fisiologis adalah manfaat terapi yoga. Yoga dapat mengatasi resiko jatuh yang diketahui (keseimbangan buruk mobilitas terganggu, kekuatan berkurang dan fleksibilitas dan peningkatan keseimbangan pada lansia) Nella, 2016.

Hasil penelitian ini sejalan dengan penelitian yang telah dilakukan (Mondal et al., 2017)dengan judul Penerapan Yoga sebagai alat yang efektif untuk meningkatkan keseimbangan postor pada dewasa muda di India yang sehat. Berdasarkan analisis statistik menggunakan SPSS menunjukkan bahwa ada peningkatan signifikan secara keseluruhan $\mathrm{F}(2,24)$ $=35,706, \mathrm{p}=0,000)$ diarea COP untuk semua lima percobaan kondisi setelah pelatihan yoga, tes posthoc menunjukkan peningkatan yang signifikan untuk lansia Mondal, 2017.

Menurut asumsi peneliti setelah $6 \mathrm{x}$ pelaksanaan senam yoga keseimbangan statis responden berada pada rentang baik dimana rerata keseimbangan pada lansia yaitu 25.33 (tinggi) Sehingga setelah dilakukan intevensi tidak ditemukannya responen dengan kategori keseimbangan statis kurang baik. Peneliti menemukan setalah responden diberikan intervensi senam yoga responden sudah mengalami peningkatan untuk mempertahankan posisi pada saat diam, dan pada saat responden diberikan dorongan pada saat posisi tertentu pasien sudah bisa untuk melawan dorongan tersebut atau sudah bisa untuk mempertahankan posisi tersebut tanpa adanya gerakan tambahan atau merubah posisi. Dan responden merasakan pada saat responden melakukan gerakan dari duduk ke berdiri responden sudah bisa berdiri tanpa bergantung ke tepi kursi 
tersebut. Berdasarkan hasil yang telah didapat maka disimpulkan bahwa umur lansia yang rentan terkena gangguan keseimbangan yaitu dari umur 55-64, dengan jenis kelamin perempuan dan pekerjaan ibu rumah tangga.

\section{B. Analisa Bivariat}

Berdasarkan penelitian yang dilakukan pada 30 responden di puskesmas Tigo Baleh Bukittinggi Tahun 2019 yang mengalami gangguan keseimbangan, menunjukkan adanya perbedaan nilai rata-rata keseimbangan statis pada lansia sebelum dan setelah pelaksanaan 6 kali senam yoga. Berdasarkan uji Wilcoxon didapatkan nilai $(\mathrm{p} \leq 0,005)$ artinya ada perbedaan rata-rata sebelum dan sesudah intervensi senam yoga. Bagi lansia yang telah melakukan latihan yoga secara teratur dapat memperkuat otot-otot yang lemah, memperbaiki fleksibilitas, meningkatkan tonus otot. Selain itu meningkatkan system vestibular sistem visual dan sistem propioseprive Tiedeman, 2013.

Latihan fisik yang dilakukan oleh lansia akan memilik dampak dalam menurunkan tingkat kesehatan lansia Tenggara, 2009. Sedangkan menurut suryanto, 2013. Lansia yang tidak olahraga secara terpogram dapat mempercepat terjadinya gangguan dan penurunan, terutama kekuatan otot akan menurun.

Hasil penelitian ini sejalan dengan penelitian yang telah dilakukan oleh (Patel, Deshmukh and Palekar,
2019). Dengan judul pengaruh Yoga terhadap keseimbangan dalam populasi geriatri yaitu dengan hasil ada penurunan yang sangat signifikan (nilai $\mathrm{p}<0,05)$ dalam nilai tes TUG antara grup A sedangkan ada peningkatan yang signifikan (nilai $\mathrm{p}<0,05$ ) dalam nilai tes TUG antara grub B Krishna, 2019. Menurut asumsi peneliti bahwa ada pengaruh pelaksanaan senam yoga terhadap keseimbangan statis pada lansia. Setelah 6 kali pelaksanaan senam yoga terlihat peningkatan keseimbangan dan cara mempertahankan posisi lansia dimana lansia terlihat tidak merasa kesulitan saat melakukan tindakan Tinetti(Tinetti, 1986). Kondisi ini menunjukan bahwa pelaksanaan senam yoga memberikan pengaruh yang baik terhadap keseimbangan statis pada lansia. Salah satu manfaat pelaksanaan senam yoga adalah pengurangan masa dan peningkatan kekuatan otot, termasuk otot-otot panggul, kaki dan tungkai yang berperan aktif dalam keseimbangan statis lansia serta mencegah atau memperlambat kehilangan fungsional otot, sehingga dengan pelaksanaan Senam Yoga lansia dapat memperbaiki dan mempertahankan keseimbangan postur tubuh pada saat diam (keseimbangan statis) pada lansia. Berdasarkan hasil yang telah didapat maka disimpulkan bahwa umur lansia yang rentan terkena gangguan keseimbangan yaitu dari umur 55-64, dengan jenis kelamin perempuan dan pekerjaan ibu rumah tangga

Tabel 2. Perbedaan Rata-Rata Keseimbangan Statis Pada lansia Sebelum dan Sesudah Pelaksanaan Senam Yoga

\begin{tabular}{|c|c|c|c|c|c|c|c|}
\hline Variabel & $\mathbf{N}$ & Mean & Min & Max & SD & MD & P-value \\
\hline Sebelum Latihan & 30 & 18.50 & 16 & 21 & $\begin{array}{l}1.5 \\
03\end{array}$ & \multirow{2}{*}{6.83} & \multirow{2}{*}{0,0005} \\
\hline Sesudah Latihan & 30 & 25.33 & 21 & 28 & $\begin{array}{l}1.6 \\
47 \\
\end{array}$ & & \\
\hline
\end{tabular}




\section{SIMPULAN}

Berdasarkan analisis penelitian yang telah dilakukan dan pembahasan, maka dapat disimpulkan bahwa pelatihan senam yoga dapat meningkatkan keseimbangan pada lansia dipuskesmas tigo baleh bukittinggi tahun 2019 .

Saran yang dapat diajukan berdasarkan kajian dalam penelitian ini adalah pelatihan senam yoga dapat dijadikan pilihan dalam latihan keseimbangan statis pada lanjut usia dengan gangguan keseimbangan statis dalam upaya memperbaiki keseimbangan dan mempertahankan kemampuan melakukan aktifitas sehari-hari serta mencegah terjadi jatuh selain itu diharapkan dijadikan acuan bagi peneliti selanjutnya untuk melakukan penelitian dengan kasus-kasus lain dalam menangani keseimbangan pada lansia.

\section{DAFTAR PUSTAKA}

Birren, J. (1995) 'Aging and Speed of Behavior: Possible Consequences for Psychological Functioning', Annual Review of Psychology. doi: 10.1146/annurev.psych.46.1.329.

Boedhi, D. (2014) 'Geriatri: Demografi Dan Epidemiologi Polulasi Lanjut Usia', in Buku Ajar Geriatri, pp. 4058.

Gribble, P. A. and Hertel, J. (2003) 'Considerations for normalizing measures of the Star Excursion Balance Test', Measurement in Physical Education and Exercise Science. $\quad$ doi: 10.1207/S15327841MPEE0702_3.

Howe, M. L. (2008) 'What Is False Memory Development the Development of? Comment on Brainerd, Reyna, and Ceci (2008)', Psychological Bulletin. doi: 10.1037/0033-2909.134.5.768.

Kemenkes RI (2017) 'Analisis Lansia di
Indonesia', Pusat data dan informasi Kementerian Kesehatan RI.

Maryam, S. et al. (2008) 'lansia', in Mengenal usia lanjut dan perawatannya

Mondal, K. et al. (2017) 'Application of Yoga as an Effective Tool for Improving Postural Balance in Healthy Young Indian Adults', InternationalJournal of Chinese Medicine, 1(2), pp. 62-69. doi: 10.11648/j.ijcm.20170102.14.

Notoadmojo, S. (2018) 'Metodelogi Penelitian Kesehaan', Indonesian Jourmal On Medical Science. doi: S0887899401003605 [pii].

Panti, D. A. N., Omega, W. and Indriati, P. A. (2012) 'Pengaruh Latihan Yoga Terhadap Penurunan Tekanan Darah Pada Lanjut Usia ( Lansia ) Di Panti Wreda Pengayoman " Pelkris " Semarang', Journal, pp. 1-8.

Patel, K. K., Deshmukh, M. and Palekar, T. (2019) 'Effect of Yoga on Balance in Geriatric Population', International Journal of Scientific Research in Science and Technology, 6(2), pp. 595-605. doi: 10.32628/ijsrst11962130.

Perdana, A. W. (2016) 'Pengaruh Pemberian Senam Yoga Untuk Mengurangi Insomnia Pada Lansia', Jurnal keperawatan.

Tinetti, M. E. (1986) 'Performance- Oriented Assessment of Mobility Problems in Elderly Patients', Journal of the American Geriatrics Society. doi: 10.1111/j.1532-5415.1986.tb05480.x.

Turocy, P. S. et al. (2011) 'National athletic trainers' association position statement: Safe weight loss and maintenance practices in sport and exercise', Journal of Athletic Training. doi: 10.4085/1062-605046.3.322. 